\title{
Kajian Optimasi Ukuran Kapal Tradisonal dan Perhitungan Hambatannya
}

\author{
Fany Laamena ${ }^{1}$, Admiral Taihutu ${ }^{2}$ \\ ${ }^{1}$ Jurusan Teknik Mesin Fakultas Teknik Universitas Pattimura, Ambon 97233 \\ *fany.laamena@fatek.unpatti.ac.id \\ ${ }^{2}$ Jurusan Teknik Mesin Universitas Pattimura \\ *admiral290814@gmail.com
}

\begin{abstract}
Abstrak Kapal tradisional yang berada pada jalur pelayaran di Maluku, khusus pada jalur pelayaran Ambon-Manipa memiliki peran penting sebagai salah satu moda transportasi di Maluku. Kapal-kapal kayu ini dibangun tanpa melalui kajian ilmiah, tetapi hanya berdasarkan pengalaman turun- temurun dalam menentukan panjang kapal, bentuk lambung, daya muat serta ukuran lainnya. Hal ini sangat berpengaruh terhadap hambatan kapal sebab jika nilai hambatannya besar, sangat mempengaruhi operasional kapal dan dapat merugikan pemilik kapal itu sendiri. Itulah sebabnya tujuan penelitian ini adalah untuk mengaji ulang secara ilmiah dengan menggambar model kapal yakni lines plan dari kapal yang terpilih dengan kecepatan yang ada, hambatan sekecil mungkin dengan daya muat sebesar mungkin. Metode AHP( Analytic Hierarchy Proces) adalah metode yang digunakkan untuk pemilihan kapal dari lima buah kapal yang ada pada jalur pelayaran Ambon- Manipa. Berdasarkan hasil survey di lapangan dan pengolahan data, terpilih KM Cahaya Rahma. Hasil yang diperoleh menggunakan aplikasi Maxsurf adalah perhitungan hidrostatik untuk mengetahui displasemen kapal atau berat kapal total saat garis air penuh sebesar 25.67 ton. Nilai hambatan dan daya kapal adalah $4.96 \mathrm{kN}$ dan $23.004 \mathrm{~kW}$ pada saat kecepat an kapal 9 knot.
\end{abstract}

Kata kunci: Kapal tradisional, AHP, Optimal, Displasemen, Hambatan, Maxsurf

\begin{abstract}
Traditional ships which are on the shipping lane in Maluku, specifically on the Ambon-Manipa shipping lane have an important role as one of the modes of transportation in Maluku. These wooden ships were built without going through scientific studies, but only based on hereditary experience in determining the length of the ship, the shape of the hull, the loading capacity and other measurements. This is very influential on ship obstacles because if the value of the obstacles is large, it greatly affects the operation of the ship and can be detrimental to the ship owner himself. That is why the purpose of this research is to review scientifically by drawing a model of the ship that is the lines plan of the selected ship with the available speed, the smallest obstacle with the greatest possible loading capacity. AHP (Analytic Hierarchy Process) method is a method used for the selection of ships from five ships in the Ambon-Manipa shipping lane. Based on the results of field surveys and data processing, KM Rahma was chosen. The results obtained using the Maxsurf application are hydrostatic calculations to determine ship displacement or total ship weight when the full water line is 25.67 tons. The value of the resistance and power of the ship is $4.96 \mathrm{kN}$ and $23,004 \mathrm{~kW}$ at the speed of 9 knots.
\end{abstract}

Keywords: traditional ship, AHP, Optimal, Resistance, Maxsurf

\section{PENDAHULUAN}

Kebutuhan kapal sebagai transportasi laut untuk penghubung antar pulau merupakan hal yang sangat penting guna menunjang pertumbuhan ekonomi khususnya di Ibukota provinsi yaitu Pulau Ambon dimana kapal-kapal beroperasi dari pulau-pulau kecil untuk mengangkut baik penumpang walaupun sedikit maupun hasil- hasil bumi. Manipa adalah salah satu Pulau kecil di Maluku yang memiliki hasil- hasil bumi yang banyak namun hanya sedikit kapal perintis yang melayani jalur pelayaran ini. Begitupun sebaliknya ketika berlayar dari Ambon, 
maka kapal akan membawa bahan pokok untuk kebutuhan masyarakat seperti beras, gula, telur dan sebagainya. Itulah sebabnya manfaat kapal-kapal tradisional ini sangat terasa untuk jalur pelayaran Ambon-Manipa.

Kapal-kapal yang beroperasi umumnya dibangun secara tradisional yakni sesuai pengalaman turun- temurun. Pemilik kapal tidak memiliki perhitungan pasti tentang penggambaran model kapal yang mencakup ukuran lengkap kapal seperti displasemen kapal, koefisien bentuk kapal, padahal data kapal ini sangat berpengaruh terhadap hambatan dan kecepatan kapal.

Lines plan dalam hal ini desain model lambung kapal, sangat berpengaruh pada gaya hambatan kapal. Semakin besar gaya hambatan, akan semakin besar pula tenaga mesin yang diperlukan. Semakin besar tenaga mesin, semakin besar ukuran dari mesin. Ini berpengaruh pada biaya untuk menyediakan mesin yang besar jika dimensi mesin besar [1]. Kapal dirancang sedemikian untuk menghasilkan kecepatan yang tinggi, hambatan sekecil mungkin dengan mengangkut muatan sebanyak mungkin. Tantangan bagi engineer kapal untuk bagaimana merancang lambung kapal dengan baik. Ada banyak penelitian tentang hambatan kapal dengan bentuk lambung yang berbeda.

Membuat perbandingan harga hambatan total antara aplikasi CFD dan Maxsurf setelah menganalisa bentuk lambung axe bow pada high speed craft tipe crew boat. Metode perhitungan hambatan total menggunakan Savitsky dan Holtrop [2].

Memvariasikan model haluan kapal untuk menganalisa pola aliran pada lambung kapal dan hasilnya berpengaruh pada pola aliran spray dan wash. Ini mengakibatkan Tahanan kapal juga berbeda, karena adanya $15 \%$ penambahan displacement. Perhitungan tahanan kapal menggunakan beberapa metode yaitu; Holtrop, Compton, dan Savitsky. Interpolasi dilakukan untuk mendapatkan nilai pendekatan gaya hambat kapal dari metode yang ada [3].

Meneliti hambatan pada perahu tradisional yang didahului dengan mendisain lambung kapal dengan metode kapal pembanding dimana dengan panjang $8.68 \mathrm{~m}$, hambatan yang dihasilkan sangat kecil 0.090 $\mathrm{kN}$ dan dayapun kecil $0.299 \mathrm{~kW}$ untuk kecepatan $4.9676 \mathrm{kn}[4]$.

Membuat program fishipro salah satu software yang diajarkan kepada para perancang kapal di galangan kapal tradisonal untuk menggambarkan desain lambung kapal dan mengetahui ukuran lengkap kapal dengan menghitung hidrostatik untuk mendapatkan ukuran kapal yang lengkap [5].

Menghitung tahanan kapal dengan beberapa variasi kecepatan secara matematis dan hasil menunjukkan bahwa bentuk lambung sangat mempengaruhi hambatan dan daya kapal yang bertambah seiring bertambahnya kecepatan kapal [6].

Pada penelitian ini akan dilakukan kajian ilmiah terhadap kapal tradisional yaitu menentukan kapal yang optimal, mendesain lines plan serta menghitung hambatan kapal tersebut sehingga dapat digunakan sebagai acuan bagi para pembuat kapal dalam membangun kapal tradisional terkhusus untuk kapal- kapal pada jalur pelayaran Ambon- Manipa.

\section{BAHAN DAN METODE}

\subsection{Konsep dan Persamaan Dasar Analytic Hierachy Proces}

AHP merupakan suatu model pendukung keputusan yang dikembangkan oleh Thomas L. Saaty. Hirarki didefinisikan sebagai suatu representasi dari sebuah permasalahan yang kompleks dalam suatu struktur multi level dimana level pertama adalah tujuan, yang diikuti level faktor, kriteria, sub kriteria, dan seterusnya ke bawah hingga level terakhir dari alternative. AHP sering digunakan sebagai metode pemecahan masalah dibanding dengan metode yang lain karena alasan Struktur yang berhirarki, sebagai konsekuesi dari kriteria yang dipilih, sampai pada subkriteria yang paling dalam, memperhitungkan validitas sampai dengan batas toleransi inkonsistensi berbagai kriteria dan alternatif yang dipilih oleh pengambil keputusan dan memperhitungkan daya tahan output analisis sensitivitas pengambilan keputusan [7].

Pada hakekatnya AHP merupakan suatu model pengambil keputusan yang komprehensif dengan memperhitungkan hal-hal yang bersifat kualitatif dan kuantitatif [9].

Mengatakan model AHP memakai persepsi manusia yang dianggap ahli sebagai input utamanya. AHP bersifat sederhana, fleksibel serta menampung kreatifitas dalam rancangannya untuk memecahkan suatu masalah yang kompleks [8].

\section{Hambatan Kapal}

Tahanan kapal pada suatu kecepatan adalah gaya fluida yang bekerja sehingga melawan 
gerakan kapal tersebut. Tahanan total $\left(\mathrm{R}_{\mathrm{T}}\right)$ kapal dapat dibagi menjadi tiga yakni tahanan viskositas $(\mathrm{Rv})$, tahanan gelombang $(\mathrm{Rw})$ dan tahanan udara $(\mathrm{Ra})$. Karena nilai tahanan udara sangat kecil yakni sekitar 4\% dari tahanan total, maka perannya sering diabaikan [11]. Hambatan perlu diatasi.

Beberapa faktor yang mempengaruhi hambatan kapal yakni ukuran kapal, kecepatan, koefisien bentuk badan kapal, displasemen berat, displasemen volume, luas permukaan basah. Ini didapat ketika membuat lines plan kapal. Selain itu, Froude number, Raynold number juga memiliki pengaruh yang penting disamping faktor lainnya.

Ada berbagai metode yang digunakan untuk menghitung besarnya hambatan kapal, diantaranya metode Harvald and Guldhammer, Taylor, Ayres's, Auf'm Keller, Holtrop, Compton, Fung, Van Oortmerssen, Series 60, dan beberapa metode lainnya. Setiap metode memiliki syarat tertentu ketika dipilih untuk digunakan.

\section{Maxsurf}

Maxsurf adalah software freeware digunakan dalam mendesain sebuah model kapal. Terdapat beberapa software di dalam maxsurf antara lain: hydromax, hull speed, seakeeper, workshop dan span. Sofware maxsurf sendiri digunakan untuk membuat lines plan dalam bentuk 3D. Model kapal dapat dilihat potongan station, buttock, shear dan 3D-nya. Maxsurf Resistance pada dasarnya adalah program prediksi resistensi. Sejumlah metode berbasis regresi dan satu metode analitis dapat digunakan untuk memprediksi resistensi bentuk lambung [6].

Resistansi total $=$ Gelombang + Kental $=$ Residuari + Gesekan .

Biasanya resistensi gesekan diprediksi menggunakan garis korelasi model-kapal ITTC atau formulasi serupa. Resistansi kental meliputi efek bentuk yang diterapkan pada resistansi gesekan sebagai berikut: Resistensi viskos $=(1$ $+\mathrm{k})$ Resistansi gesekan dimana $(1+\mathrm{k})$ adalah faktor bentuk.

Bila memungkinkan, Resistansi MAXSURF menghitung semua komponen resistensi dan ini dapat diplot dan ditabulasi secara terpisah. Dalam beberapa kasus metode regresi memprediksi resistensi residu dan tidak ada faktor bentuk. Dalam kasus ini, tidak mungkin untuk menghitung hambatan gelombang [10].

\subsection{Prosedur Penelitian}

Prosedur penelitian adalah sebagai berikut:

1. Studi literatur yakni mencari referensi yang berhubungan dengan topik penelitian berupa jurnal dan artikel.

2. Kapal- kapal pada jalur pelayaran AmbonManipa menjadi objek dari penelitian. Survei di pelabuhan Slamet Riayadi Ambon melalui wawancara dan observasi dilakukan untuk mengambil data- data kapal yaitu ukuran kapal mencakup Panjang keseluruhan (LOA), Panjang garis air (LWL), Lebar (B), Tinggi (H), Tinggi sarat $\quad(\mathrm{T})$, selain itu, ada data kecepatan kapal (Vs), daya motor, daya muat, bentuk lambung dan biaya pembuatan.

Pada jalur pelayaran tersebut ada lima buah kapal yaitu KM Tiara Sari, KM Terajana, KM Cahaya Rahma, KM Air Mata Bunda dan KM Ita Star. Dibagikan 20 kuesioner untuk diisi oleh ABK dan Pengguna jasa.

3. Membuat pemilihan kapal dengan metode AHP. Langkah penggunaan metode AHP sebagai berikut:

\section{- Penyusunan Hirarki}

- Penilaian kriteria dan sub kriteria

Nilai dan definsi dari skala perbandingan Saaty dalam Arisusanty [9] yakni

Nilai 1, Kedua variabel mempunyai pengaruh yang sama besar terhadap tujuan, nilai 3 Sedikit lebih penting, Pengalaman dan pertimbangan sedikit menyokong satu variabel atas yang lainya, nilai 5 Jelas lebih penting, Pengalaman dan pertimbangan dengan kuat menyokong satu variabel diatas yang lainnya, nilai 7 Sangat jelas penting lebih, Satu variabel dengan kuat disokong dan dominanya terlihat dalam praktek, nilai 9 Mutlak lebih penting, Bukti yang menyokong variabel satu atas variabel lainnya memiliki tingkat penegasan tertinggi yang mungkin menguatkan dan nilai 2,4,6,8 adalah nilai-nilai diantara dan pertimbangan yang berdekatan, kompromi diperlukan antara dua pertimbangan.

- Penentuan prioritas

- Konsistensi Logis

- Hasil peringkat tertinggi adalah kapal yang terpilih yakni yang optimal.

4. Mendesain ulang, lines plan kapal terpilih dengan maxsurf modeler disesuaikan dengan hasil survey ukuran utama kapal, sehingga didapatkan ukuran kapal yang lengkap, harga 
koefisien pembentuk kapal yang berpengaruh terhadap displasemen kapal.

5. Perhitungan Hambatan pada kecepatan 5-10 Knot dengan menggunakan metode Holtrop, Fung dan Oortmerssen pada aplikasi Maxsurf.

\section{HASIL DAN PEMBAHASAN}

Pada penelitian terdahulu, dalam pemilihan kapal tradisional, peneliti sendiri langsung yang memilih salah satu kapal sebagai sampel di daerah Sekupang tanpa menggunakan metode pemilihan sehingga memiliki kelemahan karena bersifat objektif [4].

Juga membuat penelitian untuk menentukkan daya kapal ikan tradisional 5 GT di daerah pesisir kepulauan Bengkalis didahului dengan pemilihan kapal tetapi hanya langsung dipilih oleh peneliti tanpa ada metode yang digunakan. Itulah sebabnya, dengan menggunakan metode AHP, dapat lebih selektif dalam membuat keputusan [6].

Optimasi ukuran kapal dapat digunakan ketika akan merancang ukuran kapal baru maupun memilih dari ukuran kapal yang telah ada. Penelitian ini mengkaji ukuran kapal dengan memilih dari beberapa ukuran yang telah ada menggunakan metode AHP.

Aspek yang digunakan untuk penilaian kapal antara lain: Ukuran Kapal, Kecepatan, Daya Motor, Daya Muat, Bentuk Lambung dan Biaya Pembuatan.



Gambar 1. Hirarki AHP kriteria pemilihan kapal yang optimal

Dari hasil di atas, maka dibuat matriks perkalian antara vector Eigen atau factor evaluasi dari masingmasing kriteria dengan faktor bobot maka akan di dapat rangking total dari masing-masing alternatif. Dari sinilah maka akan di dapat hasilnya
Tabel 1. Perangkingan AHP

\begin{tabular}{lcccc}
\hline \multicolumn{1}{c}{ Rengking } & $\begin{array}{c}\text { Ukuran } \\
\text { kapal }\end{array}$ & $\begin{array}{c}\text { Kecepatan } \\
\text { Kapal }\end{array}$ & $\begin{array}{c}\text { Daya } \\
\text { Motor }\end{array}$ & $\begin{array}{l}\text { Daya } \\
\text { Muat }\end{array}$ \\
\hline $\begin{array}{l}\text { KM. Tiara } \\
\text { Sari } \\
\text { KM. } \\
\text { Terajana }\end{array}$ & 0.059 & 0.13 & 0.058 & 0.088 \\
$\begin{array}{l}\text { KM. Cahaya } \\
\text { Rahma }\end{array}$ & 0.469 & 0.327 & 0.346 & 0.386 \\
$\begin{array}{l}\text { KM. Air } \\
\text { Mata }\end{array}$ & 0.12 & 0.098 & 0.099 & 0.228 \\
$\begin{array}{l}\text { Bunda } \\
\text { KM. Ita Star }\end{array}$ & 0.142 & 0.327 & 0.346 & 0.228 \\
\hline $\begin{array}{l}\text { Rengking } \\
\text { Bentuk }\end{array}$ & Badan & Biaya & Faktor & Peringkat \\
\hline $\begin{array}{l}\text { KM. Tiara } \\
\text { Sari }\end{array}$ & 0.062 & 0.06 & 0.362 & 0.07015 \\
$\begin{array}{l}\text { KM. } \\
\text { Terajana }\end{array}$ & 0.244 & 0.23 & 0.071 & 0.1737 \\
$\begin{array}{l}\text { KM. Cahaya } \\
\text { Rahma }\end{array}$ & 0.422 & 0.457 & 0.116 & 0.42301 \\
$\begin{array}{l}\text { KM. Air } \\
\text { Mata }\end{array}$ & 0.114 & 0.102 & 0.205 & 0.13409 \\
$\begin{array}{l}\text { Bunda } \\
\text { KM. Ita Star }\end{array}$ & 0.159 & 0.151 & 0.049 & 0.19906 \\
\hline
\end{tabular}

Berdasarkan Hasil perhitungan dengan menggunakan Metode AHP, maka berdasarkan peringkat yang dibuat maka KM Cahaya Rahma adalah Kapal dengan ukuran optimal terpilih untuk beroperasi pada jalur pelayaran Ambon-Manipa.

\subsection{Membuat Lines Plan dengan Software Maxsurf}

Data utama kapal yang didapat dari hasil penganbilan data di Lapangan adalah sebagai berikut:

$>$ Length Overall (LOA) $\quad: 17.20 \mathrm{~m}$

$>$ Length Water Line (LWL) $: 15.83 \mathrm{~m}$

$>$ Breadth (B) $\quad: 3.24 \mathrm{~m}$

$>$ Depth $(\mathrm{H}) \quad: 1.40 \mathrm{~m}$

$>\operatorname{Draft}(\mathrm{T}) \quad: 1 \mathrm{~m}$

$>$ Kecepatan (Vs) : 9 knot

$>$ Berat kapal kosong dengan perlengkapan tetap kapal seperti Mesin, dll $: \pm 9$ ton

$>$ Daya muat maksimum kapal : 11 ton 
Berat keseluruhan Kapal $\quad: \pm 20$ ton

Dari data utama kapal yang ada maka dibuat lines plane KM Cahaya Rahma menggunakkan Software Maxsurf modeler. Pemilihan tipe lambung kapal adalah proses awal sebelum memulai perancangan. Memilih tipe lambung awal berupa surface dan berbentuk kotak. Setelah dipilih, dapat ditentukan ukuran kapal terlebih dahulu, yakni ukuran panjang kapal keseluruhan, lebar, dan tinggi kapal. Setelah ukuran ditentukan, maka diputuskan jumlah station dan garis air yang dibuat. Membuat station sebanyak 20 dan garis air bejumlah 5 . Untuk hasil perancangan ditunjukkan pada Gambar 2 berikut.

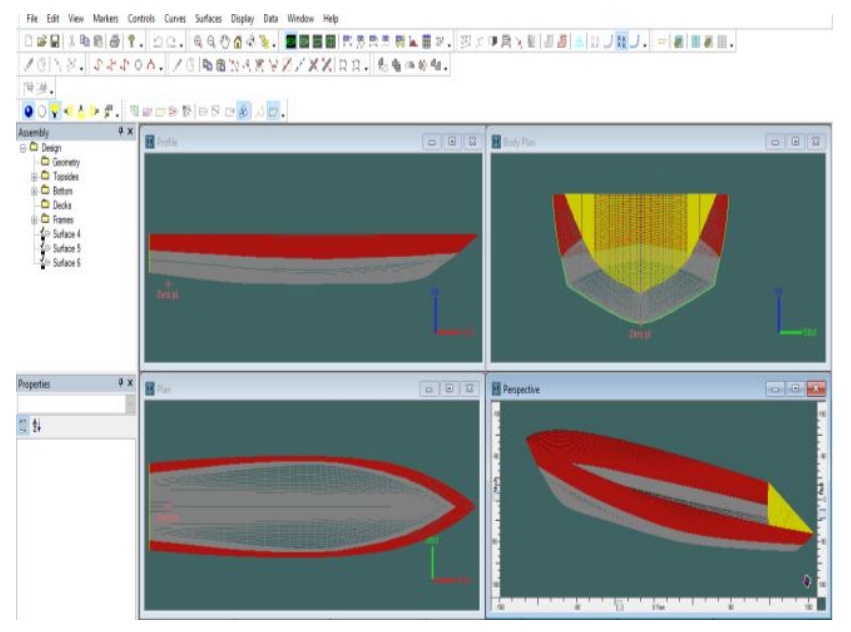

Gambar 2. Redesain kapal Cahaya Rahma pada aplikasi maxurf modeler

Menggunakan aplikasi maxsurf modeler untuk menghitung hidrostatik kapal. Yang pertama, menentukan frame of reference pada posisi longitudinal datum di midship. Base line ditentukan pada bagian bawah kapal. selanjutnya menentukan vertikal datum ada di atas base line. Akan terlihat perhitungan hidrostatik saat memilih menu Data $>$ Calculate Hydrostatic. Setelah itu akan ada tampilan menu yang berisi semua data hydrostatic kapal tersebut. Tampilannya seperti gambar 3.

Hasilnya menunjukkan bahwa nilai displasemen atau berat kapal total saat garis air penuh sebesar 25.67 ton sehingga daya muat kapal dapat bertambah dibandingkan dengan data sebelumnya.

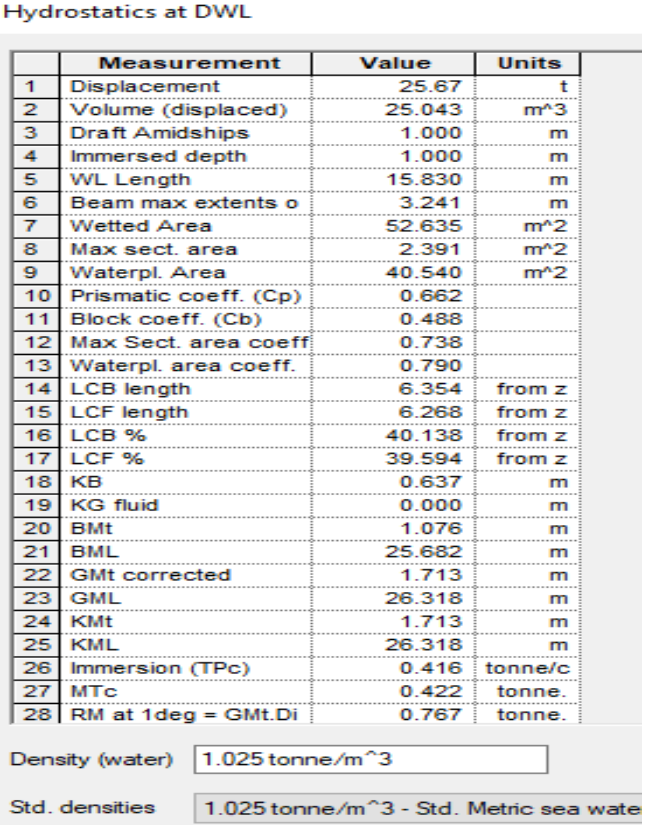

Gambar 3. Hasil perhitungan hidrostatik KM Cahaya Rahma dengan aplikasi maxurf modeler

Sebelum menghitung hambatan kapal, perlu menentukan metode analisa yang digunakan pada Maxsurf Resistance. Dalam penelitian ini dipakai 3 metode yaitu Holtrop, Van Oortmerssen, dan Fung . Kemudian menentukan rentang kecepatan kapal yang diinginkan. Pada penelitian ini ditetapkan rentang kecepatan kapal dari 5 - 10 knots.

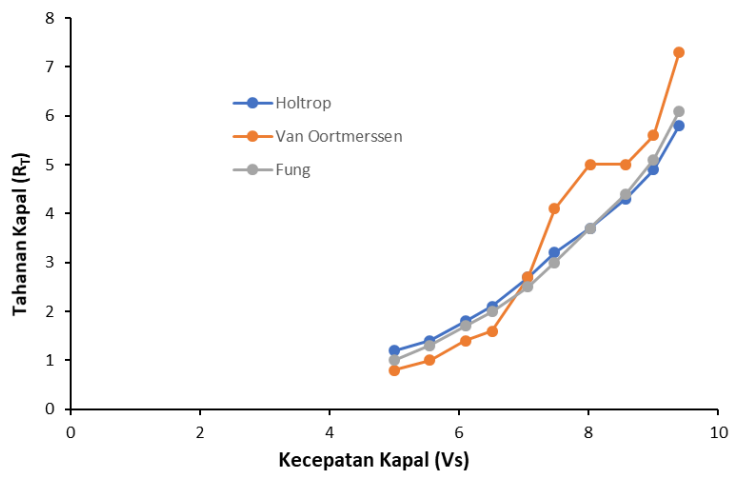

Gambar 4. Hasil perhitungan Tahanan Kapal $\left(\mathrm{R}_{\mathrm{T}}\right)$ dengan 3 metode maxurf

Hasil perhitungan menggunakan maxurf di grafik pada gambar 4 dapat dilihat bahwa kecepatan maksimum adalah 9 knot karena jika dinaikkan kecepatannya pada 10 knot maka tahanan yang dihasilkan akan semakin besar dan jika dipaksakan akan berakibat buruk pada mesin. Ini menunjukkan bahwa semakin besar kecepatan kapal, maka semakin besar hambatan yang dialami. 
Tabel 3 . Hasil perhitungan tahanan kapal dan daya kapal dari maxsurf

\begin{tabular}{llcc}
\hline No & Metode & $\begin{array}{c}\text { Hambatan } \\
(\mathbf{k N})\end{array}$ & Daya $(\mathbf{k W})$ \\
\hline 1 & Holtrop & 4.96 & 23.004 \\
2 & Fung & 5.1 & 23.685 \\
3 & Van & 5.6 & 25.969 \\
& Oortmers & & \\
& sen & & \\
\hline
\end{tabular}

Pada Tabel 3 ditunjukkan hasil simulasi yang dibuat dengan tiga metode dengan kecepatan dinas yaitu 9 knot. Berdasarkan tabel tersebut dapat terlihat bahwa besarnya hambatan dari masingmasing metode memiliki nilai yang berbeda tetapi sangat kecil dan hasilnya cenderung memiliki nilai yang sama.

\section{KESIMPULAN}

Pada penelitian ini dapat disimpulkan bahwa:

a) Berdasarkan metode AHP, maka kapal dengan ukuran seperti KM Cahaya Rahma adalah yang optimal untuk jalur pelayaran Ambon- Manipa.

b) Berdasarkan kajian Ilmiah yang telah dibuat melalui Penggambaran ulang lambung kapal yakni lines Plan KM. Cahaya Rahma di Maxsurf menghasilkan data ukuran kapal yang lengkap dan akurat diantaranya koefisien bentuk badan kapal yang mempengaruhi displacement kapal yaitu sebesar 25.67 ton yang awalnya hanya diprediksi oleh pembuat kapal sebesar 21 ton dan volume displaced $25.043 \mathrm{~m}^{3}$.

c) Hasil perhitungan nilai hambatan dan power KM. Cahaya Rahma untuk kecepatan 9 knot adalah $4.96 \mathrm{kN}$ dan $23.004 \mathrm{~kW}$ sehingga kapal masih dapat beroperasi pada kecepatan tersebut karena jika kecepatan dinaikkan maka akan berpengaruh terhadap nilai hambatan yang besar.

\section{Saran}

Kemajuan teknologi sudah dirasakan sampai ke daerah terpencil dibuktikan dengan kemampuan masyarakat dalam penggunaan banyak aplikasi pada smartphone. Untuk itu, Program Maxsurf dapat disosialisasikan pada pembuat kapal di tempat produksi kapal-kapal rakyat dengan pelatihan dan pendampingan khusus untuk lebih maju dalam produksi kapal rakyat di Maluku.

\section{DAFTAR PUSTAKA}

[1] Mufti, F.M. et al, Issue in Design of Indonesian Traditional Ships, Journal of Ocean, Mechanical and Aerospace-Science and Engineering, Vol.12, pp: 7-12, 2014.

[2] Oni, R. Dan Utama, I.K.A.P., Analisa Pengaruh Bentuk Lambung Axe Bow Pada Kapal High Speed Craft Terhadap Hambatan Total, Jurnal KAPAL, Vol. 12, No. 2, Hal. 78 - 87, 2015.

[3] Sahlan dkk, Pengaruh Bentuk Lambung Kapal Terhadap Pola Aliran dan Powering Pada Kapal Perairan Sungai dan Laut, Jurnal KAPAL, Vol 13, No 1, Hal 1-6, 2016.

[4] Mufti dkk, Perhitungan Hambatan Pada Perahu Tradisional, Jurnal Teknologi dan Riset Terapan Volume 1, Nomor 2, Hal 81-85, 2019.

[5] Andy dkk, Kajian Penggunaan Program Aplikasi Desain Kapal Tradisional Pada Galangan Kapal Kayu Di Kabupaten Batang, Jurnal Kapal Volume 12 Nomor 3, Hal 139$144,2015$.

[6] Sarwoko dan Budhi Santoso, Computational Tahanan Kapal Untuk Menentukan Daya Mesin Utama Kapal Ikan 5 GT, Jurnal Rekayasa Mesin Volume 14 No.1, Hal 23-26, 2019.

[7] Andoyo W dkk, Analisis Human Error terhadap Kecelakaan Kapal pada Sistem Kelistrikan berbasis Data di Kapal, Jurnal Teknik ITS Vol. 4, No. 1, (2015) ISSN: 2337-3539.

[8] Didiet Sudiro dkk, Pemilihan Variabel Penentu Perawatan permesinan kapal untuk menaikkan keandalan Kapal TNI AD, Jurnal Kajian Teknik Mesin No.1, Vol. 2, Hal 123-132, 2016.

[9] Arisusanty, D.J, dkk, Analisa Menentukan Kriteria Pemilihan Pelabuhan Pengumpan Tol Laut Menggunakan Metode AHP, Jurnal Albacore, vol. 2, No.1, Hal 057-067, 2018

[10] MAXSURF Resistance Program \& User Manual Bentley Systems, Incorporated. All rights reserved. Copyright () 2017.

[11] Erik Sugianto dan Arif Winarno, Computational model tahanan kapal untuk menentukan kebutuhan daya kapal bulk carrier 8664 DWT, Jurnal Kelautan, Vol.10, No.2, Hal 168-173, 2017. 